\title{
Soluble PD-1 and PD-L1: predictive and prognostic significance in cancer
}

\author{
Xinxin Zhu ${ }^{1}$ and Jinghe Lang ${ }^{1}$ \\ ${ }^{1}$ Department of Obstetrics and Gynecology, Peking Union Medical College Hospital, Peking Union Medical College, Chinese Academy \\ of Medical Sciences, Beijing, China
}

Correspondence to: Jinghe Lang, email: langjh@hotmail.com, doctorlangjh@163.com

Keywords: soluble, $P D-1, P D-L 1$, tumor immunity, biomarker

Received: April 25, $2017 \quad$ Accepted: May 22, $2017 \quad$ Published: May 31, 2017

Copyright: Zhu et al. This is an open-access article distributed under the terms of the Creative Commons Attribution License 3.0 (CC BY 3.0), which permits unrestricted use, distribution, and reproduction in any medium, provided the original author and source are credited.

\begin{abstract}
The membrane-bound molecules programmed death 1 (PD-1) and its ligand PD-L1 (PD-1/PD-L1) belong to the immune checkpoint pathway. PD-1 pathway downregulates effector $T$ cells in immune response, thereby causing immune suppression. Recent studies have revealed that membrane-bound PD-1 and PD-L1 also have soluble forms. These soluble forms increase the complexity and diversity of the composition and function of the PD-1/PD-L1 signaling pathway. However, the exact roles of these molecules remain unknown. The objective of this systematic review was to elucidate the biological significance of soluble PD-1/PD-L1 in human cancers and evaluate whether they are potential diagnostic, therapeutic, or prognostic biomarkers. We expect to provide new clues for future research on soluble PD-1/PD-L1 pathway in human malignant tumors.
\end{abstract}

\section{INTRODUCTION}

Malignant tumor cells use various methods of immune suppression to resist antitumor immunity. One of these methods is modifying the PD-1/PD-L1 pathway, which is called the "immune checkpoint" [1]. The PD-1/ PD-L1 pathway not only controls excessive immune activation normally, but also appears to be a means through which tumors evade the immune system [2]. The activation of this pathway can lead to tumor immune escape and promote tumor cell growth including the following aspects: $\mathrm{T}$ cell tolerance, $\mathrm{T}$ cell apoptosis, $\mathrm{T}$ cell exhaustion, enhancing immunosuppressive Treg cell function, inducible co-stimulatory molecule and PD-1 disbalance [3]. Therefore, immunotherapeutic agents that can improve the immune response or reduce immunosuppression are essential for treating human cancers. The current immunotherapies for malignant tumors include therapeutic vaccines, adoptive $\mathrm{T}$ cell transfer, immune modulators, cytokines, and immune checkpoint inhibitors [4]. The PD-1/PD-L1 immune checkpoint represents an available and promising pathway that can be blocked to reverse tumor-mediated immunosuppression [5-7].

PD-1 is mainly expressed on different immune cells and has two ligands, namely PD-L1 (B7-H1 or
CD274) and PD-L2 (B7-DC or CD273) [8]. Although the interaction of PD-1/PD-L2 shows a 2-6-fold higher affinity compared with the interaction of PD-1/PD-L1, PD-L1 is regarded as the primary ligand of PD-1 [9]. Recently, the soluble forms of PD-1 and PD-L1 (sPD-1 and SPD-L1) have been detected in the blood of patients with tumors [10-12]. However, the roles of SPD-1 and sPD-L1 have not been fully elucidated. This systematic review discusses the production of sPD-1/PD-L1 and evaluates the physiological and pathological significance of their levels in human blood.

\section{Structure and production of mPD-1 and mPD-L1}

T-cell immune responses are vital in adaptive antitumor immune responses through the direct killing of target tumor cells or indirect inhibition by cytokines [13]. The PD-1/PD-L1 pathway molecules including membrane-bound forms of PD-1/PD-L1 (mPD-1/PD-L1) and sPD-1/PD-L1 play immunosuppressive roles in tumor-driven T-cell immune responses [14-16]. To date, an increasing number of studies have demonstrated that the anti-mPD-1/PD-L1 monoclonal antibodies (mAbs) can reverse the immunosuppression and might serve as a promising clinical strategy for controlling human 
malignancies $[17,18]$. We will first discuss the production and expression of the classic mPD-1/PD-L1 because the fundamental knowledge of mPD-1/PD-L1 facilitates the understanding of the PD-1/PD-L1 pathway and the roles of sPD-1/PD-L1.

\section{Structure and production of mPD-1}

The $P D-1$ gene was discovered in 1992 as an upregulated gene in a T-cell hybridoma and hematopoietic progenitor cell line [19]. The components of mPD-1, a 288-amino acid (aa, $55 \mathrm{kDa}$ ) type I transmembrane glycoprotein, include an immunoglobulin (Ig) superfamily domain, stalk of approximately 20 aa, transmembrane domain, and an intracellular domain of approximately 95 aa residues. The intracellular domain contains an immunoreceptor tyrosine-based switch motif (ITSM) and an immunoreceptor tyrosine-based inhibitory motif (ITIM). ITSMs are essential for the delivery of inhibitory signals [20]. The aa sequence of PD-1 near the C-terminal tyrosine is highly conserved between humans and mice and is related to the Src homology region 2 domaincontaining phosphatase-1 (SHP-1) and SHP-2. On the contrary, the N-terminal tyrosine is not associated with either SHP-1 or SHP-2 [21].

PD-1 is expressed on active T cells, B cells, natural killer T cells, and myeloid cells such as dendritic cells (DCs), and activated monocytes [22, 23]. PD-1 expression can be induced following T-cell receptor (TCR)-mediated activation and stimulation by cytokines such as interleukin (IL)-2, IL-7, IL-15, and IL-21 [22, 24]. The mPD-1 glycoprotein is a coinhibitory molecule, which belongs to the CD28 family [25]. The expression of mPD-1 protein in a wide variety $\mathrm{T}$ lymphocytes is contrary to the limited expression of other CD28 family members, thereby implying that $\mathrm{mPD}-1$ suppresses a wider range of immune responses than do other inhibitory members of the CD28 family [26]. The role of PD-1 in the promotion of immunity evasion and development and progression of several types of malignancies, including non-small-cell lung cancer (NSCLC) [27], melanomas [28], breast cancer [29], renal cell carcinomas (RCCs) [30], and Hodgkin disease [31]has been confirmed .

\section{Structure and production of $\mathrm{mPD}-\mathrm{L1}$}

The two ligands of $\mathrm{PD}-1$ are the $\mathrm{B} 7$ family molecules, PD-L1 (B7-H1, CD274) and PD-L2 (B7-DC, CD273) [9]. PD-L1 is a 290-aa type I transmembrane glycoprotein that consists of IgC-and IgV-like extracellular domains, signal sequence, transmembrane domain, and intracellular domains [22].

The expression profile of PD-L1 is considerably more promiscuous than that of PD-1. Cells of the hematopoietic lineage, including active T cells, B cells, NK cells, DCs, monocytes, and macrophages, can express mPD-L1. It is also expressed on activated vascular endothelial cells, cultured bone marrow-derived mast cells and mesenchymal stem cells [32]. Furthermore, in humans,
mPD-L1 is extensively expressed in the tonsils, placental syncytiotrophoblasts, and lungs, where it mediates human immune tolerance [33] and human malignancies of the kidney [34], ovary [35], pancreas [36], stomach [37], esophagus [38], and liver [39]. PD-L1 mRNA or mPD-L1 protein can be upregulated by cytokines, such as IFN- $\gamma$, IL-4, IL-10, VEGF, hypoxia-inducible factor- $1 \alpha$, and the constitutive oncogene pathways, including IFN- $\gamma$ / JAK2/IFN, PI3K, and MEK/ERK/STAT1 [40, 41]. The expression levels of mPD-L1 on tumor cells tend to be associated, to some extent, with cancer progression and are predictive biomarkers of tumorigenesis, unfavorable outcomes, and improved response to treatment with PD-1/ PD-L1 blockades in gastric [42], breast [43], renal [44], and ovarian cancers [35].

\section{Mechanism of PD-1/PD-L1 signaling}

The inhibitory signaling of the PD-1 pathway was initially analyzed in the B cell line, IIA1.6, by using a chimeric molecule consisting of a PD-1 cytoplasmic region and an IgG Fc receptor type IIB extracellular region (FcPD). In the IIA1.6 cell line, co-crosslinking of B cell receptors (BCRs) and FcPD induced the phosphorylation of tyrosine residues in both ITSM and ITIM. Only the phosphorylated tyrosine residue in ITSM recruits SHP-2 through its $\mathrm{SH} 2$ domain and later phosphorylates the SHP-2 molecule. Subsequently, phosphorylated SHP-2 dephosphorylates the proximal well-known signal transducers of BCR, such as Ig $\alpha / \beta$ and Syk, which cause the deactivation of downstream molecules, including PLC $\gamma 2$, PI3K, and ERK. Finally, the deactivated signal transducers lead to the suppression of acute-phase responses such as $\mathrm{Ca}^{2+}$ mobilization as well as long-term effects such as cell growth retardation [45]. In summary, these results indicate that PD-1 suppresses BCR signals by recruiting the SHP-2 molecule to its phosphotyrosine and dephosphorylating vital signal transducers of BCR signaling (Figure 1).

In T cells, the PD-1 pathway attenuates TCR signals through similar mechanisms. PD-1 downregulates the effector phase of T-cell immune responses by elevating the threshold of T-cell activation, inhibiting T-cell proliferation, and promoting activated T-cell apoptosis. The mechanism of PD-1 signaling is associated with dephosphorylation of molecules belonging to the TCR pathway and the transmission of suppressive signals [20]. PD-1 ligation, along with TCR signaling leads to the phosphorylation of the cytoplasmic region tyrosine, followed by the recruitment of SHP-2 to C-terminal tyrosine in the ITSM. Thereafter, SHP-2 dephosphorylates TCR-related zeta-chain-associated protein kinase 70 (ZAP70) and the CD28-related PI3K pathway, thereby causing inhibition of downstream signaling (Figure 1). Moreover, blockade or inhibition of PI3K signaling activation and the subsequent cell survival gene Bcl-XL reduce IL-2 production and glucose metabolism. The 
downregulation of IL-2 further induces the anergy in CD4 ${ }^{+}$ $\mathrm{T}$ and $\mathrm{CD}^{+} \mathrm{T}$ cells $[46,47]$. Notably, phosphorylated ITSM recruits SHP-1 in addition to SHP-2, whereas the contribution of SHP-1 to the suppressive function of PD-1 is considerably less than that of SHP-2[48].

\section{Production of sPD-1 and sPD-L1}

Numerous costimulatory molecules in immunoregulation pathways assume two forms of expression, namely the membrane-bound and soluble forms. The soluble form of molecules is usually generated by proteolytic cleavage of the membrane-bound form of the costimulatory proteins, as in the case of soluble tumor necrosis factor [49] and sB7-H3 [50], or by translation of alternative spliced mRNA, as in the case of sB7-2 [51] and sCTLA-4 [52]. Similarly, the presence of soluble forms of PD-1/PD-L1 has been confirmed. Increasing evidence suggests that the blood levels of sPD-1/PDL1 might facilitate the prediction of clinicopathological characteristics, treatment response, and survival outcomes in patients with cancer $[12,53,54]$.

\section{Production of sPD-1}

Five splice variants of PD-1 mRNA transcripts have been cloned from human peripheral blood mononuclear cells: flPD-1, PD-1 Deltaex2, PD-1 Deltaex3, PD-1 Deltaex2,3, and PD-1 Deltaex2,3,4 (Figure 2). The flPD1 transcript demonstrated complete homology with the mPD-1 sequence. PD-1 Deltaex2 and PD-1 Deltaex3 are generated by alternative splicing where exon 2 and 3 (extracellular IgV-like domain and transmembrane domain, respectively) are spliced out. PD-1 Deltaex2,3 lacks exon 2 and 3. PD-1 Deltaex2,3,4 lacks exon 2, 3, and 4 (intracellular domain) and includes a premature stop codon in exon 5 [55]. PD-1 Deltaex2, PD-1 Deltaex2,3, and PD-1 Deltaex2,3,4 cannot bind to their ligands because of the lack of exon 2. The PD-1 Deltaex3 variant encodes the SPD-1, which is not detectable in healthy individuals $[55,56]$.

\section{Production of sPD-L1}

The sPD-L1, is detectable in supernatants from mPD-L1 ${ }^{+}$cell lines rather than in those from mPD-L1 ${ }^{-}$ cell lines [57], thereby indicating that mPD-L1 that is expressed on the cell surface might be a source of SPD-L1. However, other sources of SPD-L1 cannot be excluded [58]. Researchers have found that both immune [59] and tumor cells can be sources of sPD-L1 [10, 60, 61]. Among the immune cells, activated $\mathrm{T}$ cells and myeloid cells exhibit an increased level of mPD-L1, but the release of sPD-L1 is a feature of myeloid-derived cells [59]. This suggests that a regulatory mechanism that is different from that of mPD-L1 may control the production of sPD-L1. Moreover, no association was discovered between tumor PD-L1 expression (immunohistochemical analysis) and sPD-L1 levels (enzyme-linked immunosorbent assay analysis) in patients with diffuse large B-cell lymphomas (DLBCLs) and renal cell carcinomas, which indicated that the tumor microenvironment, including nonmalignant cells, may also generate sPD-L1 [62, 63].

Furthermore, sPD-L1 was expressed in normal human serum and the levels of sPD-L1 in human serum increased with age. Children aged 3-10 years had the lowest expression levels of sPD-L1, whereas adults aged 51-70 years had the highest levels $(0.725 \pm 0.181$
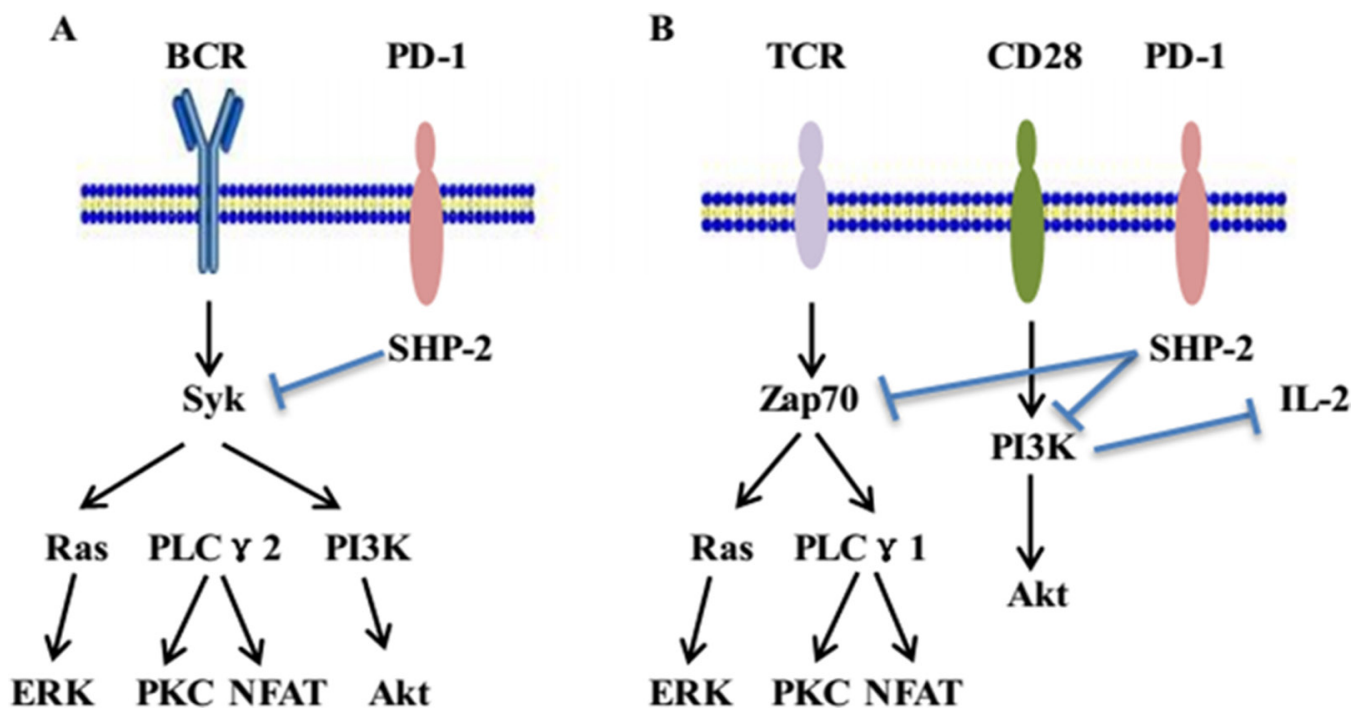

Figure 1: The inhibitory signaling of PD-1 pathway. (A) In B cells, PD-1 ligation along with BCR signaling leads to the phosphorylation of the tyrosine residue in ITSM. The phosphorylated tyrosine residue in ITSM recruits SHP-2. Thereafter, SHP-2 dephosphorylates BCR-proximal signaling molecules, including Syk, which attenuate the activation of downstream molecules. (B) In T cells, PD-1 ligation along with TCR signaling results in the phosphorylation of the tyrosine residue in ITSM and recruits SHP-2. The recruitment of SHP-2 dephosphorylates signaling through the PI3K or Zap70 pathways and inhibits of downstream signaling. Meanwhile, blockade of PI3K activation and the subsequent downregulation of IL-2 further induces CD8+ and CD4 ${ }^{+}$T-cell anergy. 
$\mathrm{ng} / \mathrm{mL}$ vs $1.040 \pm 0.681 \mathrm{ng} / \mathrm{mL}$, respectively) [57]. Moreover, the sPD-L1 levels might increase when matrix metalloproteinases (MMPs) cleave the extracellular fraction of mPD-L1; therefore, the production of SPD-L1 is suppressed by MMP inhibitors [20, 57]. However, whether the cleavage occurs randomly or is controlled by unique mechanisms remains to be determined.

\section{Functions of sPD-1 and sPD-L1}

Tumor-related mPD-1 and mPD-L1 contribute to tumor immune escape $[64,65]$. Immunotherapeutic strategies against malignant tumors using their antagonists have aroused researchers' intense interest. The sPD-1/PDL1 may represent unanticipated elements that contribute to immune response as well.

\section{Functions of sPD-1}

Several studies on the functions of sPD-1 are based on animal models. In a study on murine hepatocarcinoma, the eukaryotic expression plasmid encoded SPD-1 protein was constructed, and its significant improvement in the antitumor immunity was proven [66]. Later, researchers used the adeno-associated virus to deliver SPD-1 into tumor sites, which inhibited H22 hepatoma cell growth, enhanced lysis of cancer cells and finally prolonged the overall survival (OS) of tumor-bearing mice [67].

As aforementioned, the importance of the PD-1 checkpoint pathway in T-cell anergy and immunosuppression has been confirmed[68]. In this regard, antibody-based checkpoint blockades to reverse T-cell function in cancer immunotherapies have a promising future. Several PD-1/PDL1 pathway blocking monoclonal antibodies (mAb), such as nivolumab [69], pembrolizumab [70], pidilizumab [71], durvalumab [72], and atezolizumab [73], have either entered into clinical trials or have been approved for clinical treatment and have shown potent therapeutic efficacies in multiple advanced-stage tumors. Studies have hypothesized that binding of sPD-1 to mPD-L1/mPD-L2 may prevent mPD-1 from combining with PD-L1 and PD-L2, thereby counteracting
mPD-1-mediated inhibitory effects on T cells [57]. On one hand, the PD-1/mPD-L1 combination could provide direct inhibitory signal for $\mathrm{T}$ cells in the immune response. On the other hand, a great deal of sPD-L1 could afford distant influence to the activated T cells by the intervention of PD-1/ mPD-L1 interactions. Moreover, sPD-1 may be more effective and potent than anti-PD-1 mAb for the following reasons: first, sPD-1 can suppress all three combinations (PD-L1:PD-1, PDL2:PD-1, and PD-L1:B7-1(CD80)) that inhibit T-cell immune responses (Figure 3) [74]. Second, unlike mAb immunotherapy, the sustained but lower level of serum SPD-1 may reduce side effects while still exerting a relatively strong therapeutic effect [75]. Third, sPD-1 is more cost effective than $\mathrm{mAb}$ as the latter necessitates high and frequent doses [74].

In addition, the use of SPD-1 combined with other agents produced promising outcomes in vitro experiments. Blockade of tumor PD-1 pathway by hydrodynamic injection of plasmid DNA encoding SPD-1 and tumorderived heat shock protein-70 (HSP70) peptide complexes reduced pulmonary metastasis of $\mathrm{B} 16 \mathrm{~F} 1$ melanoma cells and therefore increased the OS rate in female C57BL/6 mice [75]. Similarly, the in vitro coadministration of human papilloma virus-16 E7 DNA vaccine with sPD1 DNA considerably improved E7-specific $\mathrm{CD}^{+}$T-cell responses, leading to valid antitumor effects against E7-expressing tumors [74]. The codelivery of sPD-1 DNA increased the maturation of DCs, which was accompanied by upregulation of DC maturation markers such as major histocompatibility complex II (MHC II) [74]. Considering that DC maturation is mediated by activated $\mathrm{T}$ lymphocytes, we speculate that $\mathrm{DC}$ maturation upregulated by SPD-1 might be influenced by the augmentation of T-cell responses. All these findings indicate that the SPD-1 plays an adjuvant role in enhancing antigen-specific T-cell immunity responses.

A few clinical studies have analyzed the relationship between the level of SPD-1 in blood and clinicopathological characteristics in patients with cancer for evaluating the predictive role of sPD-1 (Table 1) $[53,76,77]$. In patients with NSCLC, a study

\begin{tabular}{|l|l|l|l|l|}
\hline exon 1 & exon 2 & exon 3 & exon 4 & exon 5 \\
fIPD-1
\end{tabular}

\begin{tabular}{|l|l|l|l|}
\hline exon 1 & exon 3 & exon 4 & exon 5 \\
\hline
\end{tabular}

\begin{tabular}{|l|l|l|l|}
\hline exon 1 & exon 2 & exon 4 & exon 5 \\
\hline
\end{tabular}

\begin{tabular}{|l|l|l|}
\hline exon 1 & exon 4 & exon 5 \\
\hline
\end{tabular}

$$
\begin{array}{|l|l|}
\text { exon } 1 & \text { exon } 5 \\
\hline
\end{array}
$$

\section{PD-1 Deltaex2}

\author{
PD-1 Deltaex3
}

PD-1 Deltaex2,3

PD-1 Deltaex2,3,4

Figure 2: Different PD-1 splice variants. Five splice variants of PD-1 mRNA transcripts have been cloned from human peripheral blood mononuclear cells: flPD-1, PD-1 Deltaex2, PD-1 Deltaex3, PD-1 Deltaex2,3, and PD-1 Deltaex2,3,4. 
Table 1: Studies on clinical significance of SPD-1 and SPD-L1 in human cancer

\begin{tabular}{|c|c|c|c|c|c|}
\hline & Tumor & $\mathbf{n}$ & Aim & Outcomes & Ref \\
\hline \multirow[t]{3}{*}{ sPD-1 } & NSCLC & 38 & $\begin{array}{l}\text { To compare the concentration } \\
\text { of sPD-1 in patients with EGFR } \\
\text { mutation prior to erlotinib } \\
\text { treatment and at the time of } \\
\text { progression and to correlate } \\
\text { these results to patient outcome. }\end{array}$ & $\begin{array}{l}\text { 1. The serum concentration of sPD-1 increased } \\
\text { during erlotinib treatment; } \\
\text { 2. An increase in sPD-1 during treatment was } \\
\text { associated with prolonged PFS (adjusted HR }= \\
0.32, p=0.013 \text { ) and OS (adjusted HR }=0.33, p= \\
0.006 \text { ). }\end{array}$ & [53] \\
\hline & OSCC & 107 & $\begin{array}{l}\text { To detect the expression levels } \\
\text { of sPD- } 1 \text { in OSCC patients and } \\
\text { to discuss their biological and } \\
\text { clinical significance. }\end{array}$ & $\begin{array}{l}\text { There was no difference between the OSCC } \\
\text { group and the control group }(p>0.05) \text {. }\end{array}$ & [77] \\
\hline & $\mathrm{HCC}$ & 2903 & $\begin{array}{l}\text { To assess the impact of sPD-1 } \\
\text { levels on long-term dynamics of } \\
\text { HBV load and HCC risk. }\end{array}$ & $\begin{array}{l}\text { 1. The levels of sPD-1 were positively associated } \\
\text { with HCC risk for men; } \\
2 \text {. The elevated sPD-1 levels maintained higher } \\
\text { viral load for } 4 \text { or more years; } \\
3 \text {. High levels of viral load and sPD-1 was } \\
\text { associated with a } 6.29 \text {-fold increase in risk of HCC. }\end{array}$ & [76] \\
\hline \multirow[t]{6}{*}{ sPD-L1 } & OSCC & 107 & $\begin{array}{l}\text { To detect the expression levels } \\
\text { of sPD-L1 in OSCC patients and } \\
\text { to discuss their biological and } \\
\text { clinical significance. }\end{array}$ & $\begin{array}{l}\text { 1. The average of sPD-L1 was remarkably higher } \\
\text { in OSCC group }(p<0.05) \text {; } \\
\text { 2. sPD-L1 expression was related to clinical } \\
\text { stage, tumor cell differentiation, and lymph node } \\
\text { status }(p<0.05) \text {. }\end{array}$ & {$[77]$} \\
\hline & NNKTL & 40 & $\begin{array}{l}\text { To examine the expression of } \\
\text { sPD- } 1 \text { in NNKTL. }\end{array}$ & $\begin{array}{l}\text { 1. The sPD-L1 level was significantly increased } \\
\text { in NNKTL patients }(p=0.0074) \text {; } \\
2 \text {. The high-sPD-L1 group of patients showed } \\
\text { significantly worse } 5 \text {-year OS than the low- } \\
\text { sPD-L1 group }(p=0.0332) \text {. }\end{array}$ & [12] \\
\hline & MM & 96 & $\begin{array}{l}\text { To serum sPD-L1 } \\
\text { levels in patients. }\end{array}$ & $\begin{array}{l}\text { 1. MM patients had higher sPD-L1 concentrations } \\
\text { than healthy controls }(p<0.0001) \text {; } \\
\text { 2. The overall response rate to treatment was } \\
\text { higher in low sPD-L1 patients than in high } \\
\text { sPD-L1 patients }(p=0.006) \text {; } \\
\text { 3. Patients with lower sPD-L1 levels had higher } \\
\text { 3-year PFS and OS rates }(p<0.05) \text {. }\end{array}$ & [54] \\
\hline & NSCLC & 174 & $\begin{array}{l}\text { To evaluate the association } \\
\text { between SPD-L1 expression and } \\
\text { clinical characteristics in patients } \\
\text { with advanced NSCLC. }\end{array}$ & $\begin{array}{l}\text { 1. The expression of sPD-L1 in advanced NSCLC } \\
\text { patients was significantly upregulated compared } \\
\text { with the healthy control }(p<0.001) \text {; } \\
\text { 2. The expression of sPD-L1 was significantly } \\
\text { correlated with abdominal organ metastasis }(p=0.004) \text {; } \\
\text { 3. A high sPD-L1 expression had a worse } \\
\text { prognosis than a low expression in patients } \\
(p<0.001) \text {. }\end{array}$ & {$[3]$} \\
\hline & ccRCC & 172 & $\begin{array}{l}\text { To determine whether sB7-H1 } \\
\text { levels in patients with ccRCC } \\
\text { are associated with pathologic } \\
\text { features and patient outcome. }\end{array}$ & $\begin{array}{l}\text { 1. Higher preoperative sB7-H1 levels were } \\
\text { associated with larger tumors }(p<0.001) \text {, tumors } \\
\text { of advanced stage }(p=0.017) \text { and grade }(p= \\
0.044) \text {, and tumors with necrosis }(p=0.003) \text {; } \\
2 . \text { A doubling of sB7-H1 levels was associated } \\
\text { with a } 41 \% \text { increased risk of death }(p=0.010) \text {. }\end{array}$ & [60] \\
\hline & DLBCL & 348 & $\begin{array}{l}\text { To evaluate the clinical impact } \\
\text { of sPD-L1 level measured at } \\
\text { the time of diagnosis for newly } \\
\text { diagnosed DLBCL. }\end{array}$ & $\begin{array}{l}\text { 1. Patients with elevated sPD-L1 experienced a } \\
\text { poorer prognosis with a } 3 \text {-year OS }(p<0.001) \text {; } \\
\text { 2. SPD-L1 was found elevated in patients at } \\
\text { diagnosis compared with healthy subjects and its } \\
\text { level dropped back to normal value after CR. }\end{array}$ & [62] \\
\hline
\end{tabular}




\begin{tabular}{|c|c|c|c|c|}
\hline NSCLC & 588 & $\begin{array}{l}\text { To investigate the PD-L1 } \\
\text { polymorphism and the level of } \\
\text { sPD-L1 in NSCLC. }\end{array}$ & $\begin{array}{l}\text { 1. NSCLC patients showed increased levels of } \\
\text { sPD-L1 compared to controls }(p<0.001) \text {; } \\
\text { 2. Lung adenocarcinoma patients had higher } \\
\text { sPD-L1 levels than patients with squamous cell } \\
\text { carcinoma }(p<0.01) \text {; } \\
\text { 3. No association was observed between } \\
\text { the different genetic variants and plasma } \\
\text { concentrations of sPD-L1. }\end{array}$ & [78] \\
\hline $\mathrm{HCC}$ & 279 & $\begin{array}{l}\text { To investigate the prognostic } \\
\text { value of sPD-L1 in HCC } \\
\text { patients. }\end{array}$ & $\begin{array}{l}\text { 1. Soluble PD-L1 levels positively } \\
\text { correlated with the stage of cirrhosis and with } \\
\text { stages of HCC; } \\
\text { 2.Patients with high serum sPD-L1 concentrations } \\
\text { had an increased mortality risk }(p<0.001) \text {. }\end{array}$ & [79] \\
\hline $\mathrm{MM}$ & 89 & $\begin{array}{l}\text { To analyze the levels of sPD-L1 } \\
\text { in bone marrow plasma from } \\
61 \text { patients with MM at } 100 \text { days } \\
\text { after AuHSCT. }\end{array}$ & $\begin{array}{l}\text { The higher levels of sPD-L1 had a shorter } \\
\text { response period ( } p=0.002) \text { as well as shorter } \\
\text { OS }(p=0.043) \text { than those in the normal-to-low- } \\
\text { group. }\end{array}$ & [80] \\
\hline $\begin{array}{l}\text { Lung } \\
\text { cancer }\end{array}$ & 96 & $\begin{array}{l}\text { To analyze the correlations of } \\
\text { the sPD-L1 levels with clinico- } \\
\text { pathological status, laboratory } \\
\text { data, and survival of the patients. }\end{array}$ & $\begin{array}{l}\text { 1. OS was significantly reduced in patients with } \\
\text { high compared with low sPD-L1 levels }(p= \\
0.037) \text {; } \\
\text { 2. Multivariate analysis revealed that high } \\
\text { sPD-L1 levels were significantly related to poor } \\
\text { prognosis }(\mathrm{HR}=1.99, p=0.041) \text {. }\end{array}$ & [82] \\
\hline $\begin{array}{l}\text { Gastric } \\
\text { cancer }\end{array}$ & 120 & $\begin{array}{l}\text { To evaluate the association } \\
\text { between SPD-L1 expression } \\
\text { and prognosis in patients. }\end{array}$ & $\begin{array}{l}\text { 1.The expression of sPD-L1 in } \\
\text { cancer patients was significantly up-regulated } \\
\text { compared with health people }(p=0.006) \text {; } \\
\text { 2. The expression of sPD-L1 was significantly } \\
\text { correlated with differentiation }(p=0.026) \text { and } \\
\text { lymph node metastasis }(p=0.041) \text {; } \\
\text { 3. The adenocarcinoma patients with higher } \\
\text { up-regulated PD-L1 expression had much better } \\
\text { prognosis than low expression patients ( } p= \\
0.028) \text {. }\end{array}$ & [81] \\
\hline
\end{tabular}

AuHSCT: autologous hematopoietic stem cell transplantation; ccRCC: clear cell renal cell carcinoma; CR, complete remission; DLBCL: diffuse large B-cell lymphoma; EGFR: epidermal growth factor receptor; HBV: hepatitis B virus; HCC: hepatocellular carcinoma; HR: hazard ratio; MM: multiple myeloma; n: total number; NNKTL: nasal natural killer/Tcell lymphoma; NSCLC: non-small cell lung cancer; OS: overall survival; OSCC: oral squamous cell carcinoma; PFS: progression-free survival; Ref: reference; sPD-1: soluble programmed death 1; sPD-L1: soluble programmed death ligand 1.

investigated the change in concentration of SPD-1 in the blood at initiation of erlotinib treatment and at the time of clinical resistance to erlotinib. It reported that patients with increased sPD-1 levels during erlotinib treatment were associated with prolonged progression-free survival $(p=$ $0.013)$ and $\mathrm{OS}(p=0.006)$ [53]. By contrast, in hepatitis $\mathrm{B}$ virus (HBV)-related hepatocellular carcinoma (HCC), Cheng et al. [76] assessed the effect of sPD-1 levels on the long-term dynamics of HBV load and HCC risk. They found that the longitudinal effects of increased SPD-1 level maintained higher viral loads for 4 years or more, and plasma quartile SPD-1 levels were positively related to HCC risk in men. Additional studies are needed to explore the potential and precise mechanisms underlying the discovered association between sPD-1 and malignant tumors.

\section{Functions of sPD-L1}

In contrast to SPD-1, a higher number of studies has been conducted on the mechanisms and functions of sPD-L1 in humans than in animal models (Table 1) $[3,12,54,60,62,77-82]$. At present, whether sPD-L1 can bind to PD-1, similarly to mPD-L1, and deliver an inhibitory signal is debatable. Wan et al. [56] showed that the levels of sPD-1 and sPD-L1 were considerably higher in the serum and synovial fluid samples of patients with rheumatoid arthritis compared with controls. In vitro 
experiments, $\mathrm{CD}^{+} \mathrm{T}$ lymphocytes were cocultured with synovial fluid mononuclear cells. The addition of PD-1 or PD-L1 fusion proteins at a concentration range higher than $20 \mathrm{ng} / \mathrm{mL}$ led to a significantly increased level of T-cell proliferation which can express mPD-1 or mPD-L1. This finding suggested that the properties of mPD-1 and mPD-L1 are upregulated by their soluble forms.

On the basis of the predictive role of sPD-L1, Zheng et al. [81] designed a study to evaluate the correlation between SPD-L1 level and the prognosis of patients with advanced gastric cancer. They discovered that the higher level of sPD-L1 was correlated with differentiated cancer and the absence of lymph node metastasis ( $p=0.026$ and $p=0.041$, respectively). Moreover, in this study, the adenocarcinoma patients with higher levels of sPD-L1 had better prognosis than did low-level patients $(p=0.028)$. However, on the contrary, other studies have revealed that the sPD-L1 levels may indicate a poor prognosis or treatment resistance [62, 79, 82]. Frigola et al. [59] discovered that the exposure of $\mathrm{CD}^{+}$and $\mathrm{CD}^{+} \mathrm{T}$ lymphocytes to either tumor cell-derived SPD-L1 or mature DCs-derived
sPD-L1 induced apoptosis. Similarly, Zhang et al. [3] reported that the average levels of SPD-L1 in patients with advanced NSCLC and healthy controls were significantly different $(0.723 \pm 0.081$ vs $0.565 \pm 0.048 \mathrm{ng} /$ $\mathrm{mL}$, respectively, $p<0.001)$. In addition, the median OS in the low- and high-level groups were 26.8 (95\% CI: 26.2 27.4 months) and 18.7 months (95\% CI: 15.9 21.5 months), respectively. This suggested that patients with a low sPD-L1 levels may have a longer survival time. A French multicenter clinical trial revealed that patients with elevated SPD-L1 experienced a poorer prognosis $(p<0.001)$ than did the controls, and the sPD-L1 level returned to its normal value after complete remission of DLBCL. Therefore, sPD-L1 may be a potent predicting biomarker in DLBCL, which indicates the utility of alternative therapeutic strategies [62]. Several other studies have also confirmed that SPD-L1 is a negative therapeutic and prognostic biomarker in malignant tumors, such as multiple myeloma [54] and renal cell carcinoma [60]. However, to date, the reasons of sPDL1 for the dichotomous effects on T lymphocytes remain unknown.

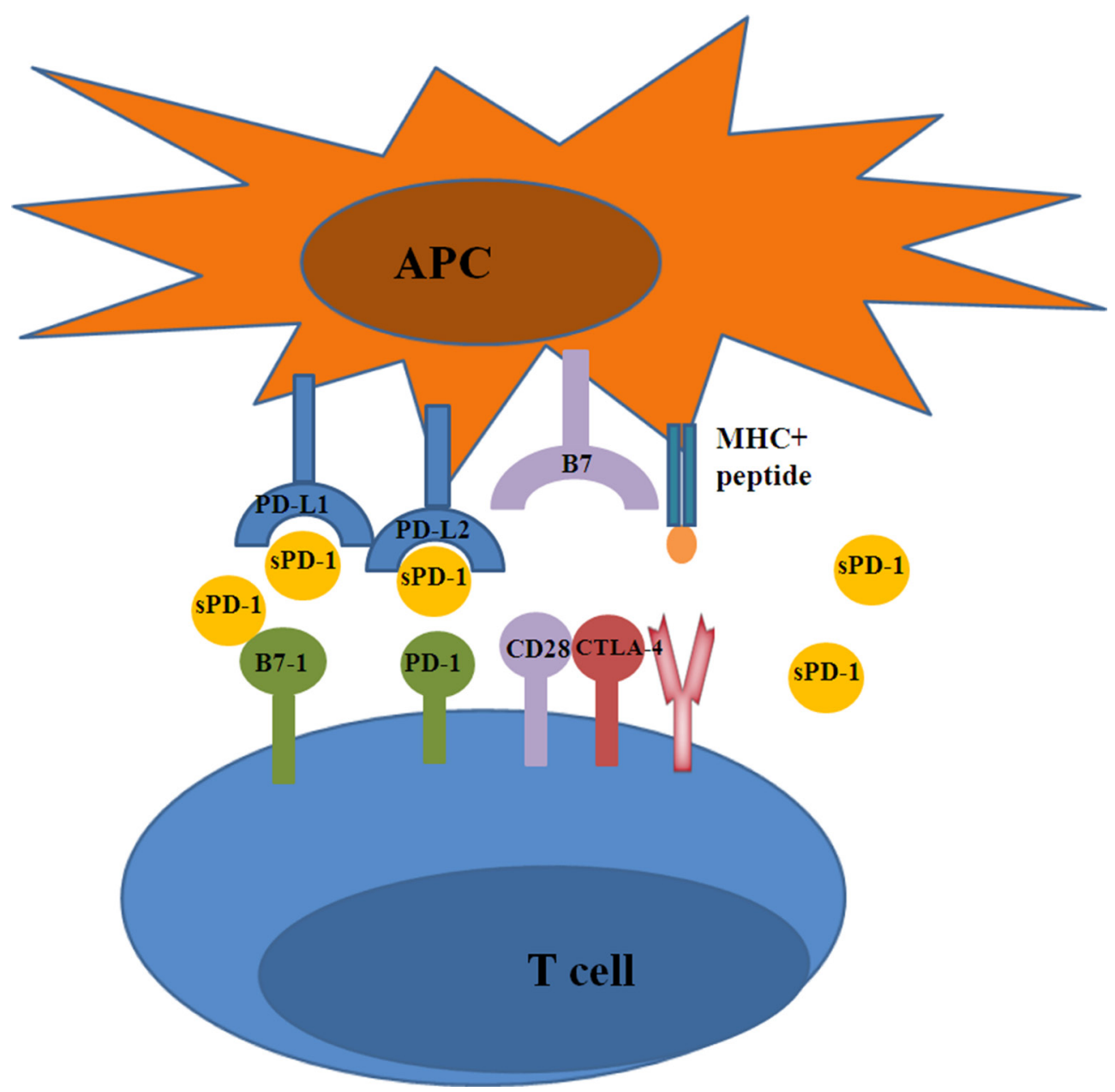

Figure 3: The blocking function of sPD-1. sPD-1 promotes $\mathrm{T}$ cell responses through blocking the following three interactions: PD-L1:B7-1, PD-L1:PD-1, and PD-L2:PD-1. 


\section{CONCLUSIONS}

In recent years, with the growth of economies and improvement in living standards, cancer incidence and mortality have increase significantly [83]. Cancer is the leading cause of death in China and is a major public health problem [84]. The detection and evaluation of cancer through mass screening and by using less invasive and more efficient markers are major public health requirements. Mass screening biomarkers, such as alpha-fetoprotein [85], antigen [86], carbohydrate antigen (CA) 19-9 and CA125 [87], prostate-specific antigen [88], and lactate dehydrogenase [89], are generally used in clinical practice; however, they do not accurately or completely predict diagnosis, disease development, immunotherapeutic sensitivity, and prognosis. Accumulated data indicates that sPD-1 and sPD-L1, which can be easily detected in clinical practice, may play significant roles in tumor pathogenesis, immune responses, and prediction. Therefore, sPD-1/PD-L1 may provide new biomarkers and insight into potential treatment strategies including immunotherapy in malignant tumor.

In addition, the treatment strategies targeting PD1/PD-L1 with mAbs such as nivolumab, pembrolizumab, and atezolizumab and so on exhibited promising results and fundamentally changed cancer treatments [90]. However, apart from the dichotomous effect of SPD-L1, the PD-1 pathway is complex and the molecular mechanisms remain unclear. Whether the PD-1 pathway $\mathrm{mAbs}$ can upregulate the antitumor responses of sPD1/PD-L1 need further study. Moreover, the synergistic therapeutic effects of sPD-1 in combination with other antitumor agents, such as HSP70 peptide vaccine [75] and IL-21 [91], provide a new direction for future antitumor strategies.

The PD-1 pathway has generated immense academic and commercial interest in the fight against cancer [92]. The application of sPD-1 and SPD-L1 in the treatment of tumors is defined to date, but their initial results appear promising. We speculate that with the growing number of successful clinical trials associated with PD-1 pathway mAbs, additional investigations and studies on SPD-1 and sPD-L1 in cancers will soon be conducted.

\section{Ethical approval}

This article does not contain any studies with human participants or animals performed by any of the authors.

\section{Authors' contributions}

Xinxin Zhu contributed to data collection, discussing content and writing. Jinghe Lang design and review the article.

\section{CONFLICTS OF INTEREST}

No potential conflict of interest relevant to this article is reported.

\section{REFERENCES}

1. Hamanishi J, Konishi I. [Targeting the PD-1/PD-L1 immune checkpoint signal - a new treatment strategy for cancer]. Gan To Kagaku Ryoho. 2014; 41:1071-76.

2. Mahoney KM, Freeman GJ, McDermott DF. The Next Immune-Checkpoint Inhibitors: PD-1/PD-L1 Blockade in Melanoma. Clin Ther. 2015; 37:764-82.

3. Zhang J, Gao J, Li Y, Nie J, Dai L, Hu W, Chen X, Han J, Ma X, Tian G, Wu D, Shen L, Fang J. Circulating PD-L1 in NSCLC patients and the correlation between the level of PD-L1 expression and the clinical characteristics. Thorac Cancer. 2015; 6:534-38.

4. Kandalaft LE, Powell DJ Jr, Coukos G. A phase I clinical trial of adoptive transfer of folate receptor-alpha redirected autologous T cells for recurrent ovarian cancer. J Transl Med. 2012; 10:157.

5. Ge Y, Xi H, Ju S, Zhang X. Blockade of PD-1/PD-L1 immune checkpoint during DC vaccination induces potent protective immunity against breast cancer in hu-SCID mice. Cancer Lett. 2013; 336:253-59.

6. McClanahan F, Hanna B, Miller S, Clear AJ, Lichter P, Gribben JG, Seiffert M. PD-L1 checkpoint blockade prevents immune dysfunction and leukemia development in a mouse model of chronic lymphocytic leukemia. Blood. 2015; 126:203-11.

7. Topalian SL, Drake CG, Pardoll DM. Targeting the PD-1/ B7-H1(PD-L1) pathway to activate anti-tumor immunity. Curr Opin Immunol. 2012; 24:207-12.

8. Latchman Y, Wood CR, Chernova T, Chaudhary D, Borde M, Chernova I, Iwai Y, Long AJ, Brown JA, Nunes R, Greenfield EA, Bourque K, Boussiotis VA, et al. PD-L2 is a second ligand for PD-1 and inhibits T cell activation. Nat Immunol. 2001; 2:261-68.

9. Youngnak P, Kozono Y, Kozono H, Iwai H, Otsuki N, Jin H, Omura K, Yagita H, Pardoll DM, Chen L, Azuma M. Differential binding properties of B7-H1 and B7-DC to programmed death-1. Biochem Biophys Res Commun. 2003; 307:672-77.

10. Shi MH, Xing YF, Zhang ZL, Huang JA, Chen YJ. [Effect of soluble PD-L1 released by lung cancer cells in regulating the function of T lymphocytes]. Zhonghua Zhong Liu Za Zhi. 2013; 35:85-88.

11. Xing YF, Zhang ZL, Shi MH, Ma Y, Chen YJ. [The level of soluble programmed death-1 in peripheral blood of patients with lung cancer and its clinical implications]. Zhonghua Jie He He Hu Xi Za Zhi. 2012; 35:102-06.

12. Nagato $T$, Ohkuri $T$, Ohara $K$, Hirata $Y$, Kishibe $K$, Komabayashi Y, Ueda S, Takahara M, Kumai T, Ishibashi 
K, Kosaka A, Aoki N, Oikawa K, et al. Programmed deathligand 1 and its soluble form are highly expressed in nasal natural killer/T-cell lymphoma: a potential rationale for immunotherapy. Cancer Immunol Immunother. 2017; 66:877-90.

13. Palucka AK, Coussens LM. The Basis of Oncoimmunology. Cell. 2016; 164:1233-47.

14. Park HJ, Park JS, Jeong YH, Son J, Ban YH, Lee BH, Chen L, Chang J, Chung DH, Choi I, Ha SJ. Correction: PD-1 Upregulated on Regulatory T Cells during Chronic Virus Infection Enhances the Suppression of CD8+ T Cell Immune Response via the Interaction with PD-L1 Expressed on CD8+ T Cells. J Immunol. 2015; 195:5841-42.

15. Riella LV, Paterson AM, Sharpe AH, Chandraker A. Role of the PD-1 pathway in the immune response. Am J Transplant. 2012; 12:2575-87.

16. Xiao H, Huang B, Yuan Y, Li D, Han LF, Liu Y, Gong W, Wu FH, Zhang GM, Feng ZH. Soluble PD-1 facilitates 4-1BBL-triggered antitumor immunity against murine $\mathrm{H} 22$ hepatocarcinoma in vivo. Clin Cancer Res. 2007; 13:1823-30.

17. Hamanishi J, Mandai M, Matsumura N, Abiko K, Baba T, Konishi I. PD-1/PD-L1 blockade in cancer treatment: perspectives and issues. Int J Clin Oncol. 2016; 21:462-73.

18. Zheng P, Zhou Z. Human Cancer Immunotherapy with PD-1/PD-L1 Blockade. Biomark Cancer. 2015 (Suppl 2); $7: 15-18$.

19. Ishida Y, Agata Y, Shibahara K, Honjo T. Induced expression of PD-1, a novel member of the immunoglobulin gene superfamily, upon programmed cell death. EMBO J. 1992; 11:3887-95.

20. Dai S, Jia R, Zhang X, Fang Q, Huang L. The PD-1/PD-Ls pathway and autoimmune diseases. Cell Immunol. 2014; 290:72-79.

21. Starr R, Willson TA, Viney EM, Murray LJ, Rayner JR, Jenkins BJ, Gonda TJ, Alexander WS, Metcalf D, Nicola NA, Hilton DJ. A family of cytokine-inducible inhibitors of signalling. Nature. 1997; 387:917-21.

22. Keir ME, Butte MJ, Freeman GJ, Sharpe AH. PD-1 and its ligands in tolerance and immunity. Annu Rev Immunol. 2008; 26:677-704.

23. Lee J, Zhuang Y, Wei X, Shang F, Wang J, Zhang Y, Liu X, Yang Y, Liu L, Zheng Q. Contributions of PD-1/PDL1 pathway to interactions of myeloid DCs with T cells in atherosclerosis. J Mol Cell Cardiol. 2009; 46:169-76.

24. Kinter AL, Godbout EJ, McNally JP, Sereti I, Roby GA, O'Shea MA, Fauci AS. The common gamma-chain cytokines IL-2, IL-7, IL-15, and IL-21 induce the expression of programmed death-1 and its ligands. J Immunol. 2008; 181:6738-46.

25. Chinai JM, Janakiram M, Chen F, Chen W, Kaplan M, Zang X. New immunotherapies targeting the PD-1 pathway. Trends Pharmacol Sci. 2015; 36:587-95.

26. Gianchecchi E, Delfino DV, Fierabracci A. Recent insights into the role of the PD-1/PD-L1 pathway in immunological tolerance and autoimmunity. Autoimmun Rev. 2013; 12:1091-100.

27. Garon EB, Rizvi NA, Hui R, Leighl N, Balmanoukian AS, Eder JP, Patnaik A, Aggarwal C, Gubens M, Horn L, Carcereny E, Ahn MJ, Felip E, et al, and KEYNOTE-001 Investigators. Pembrolizumab for the treatment of non-small-cell lung cancer. N Engl J Med. 2015; 372:2018-28.

28. Tsai KK, Zarzoso I, Daud AI. PD-1 and PD-L1 antibodies for melanoma. Hum Vaccin Immunother. 2014; 10:3111-16.

29. Haghshenas MR, Naeimi S, Talei A, Ghaderi A, Erfani N. Program death 1 (PD1) haplotyping in patients with breast carcinoma. Mol Biol Rep. 2011; 38:4205-10.

30. Massari F, Santoni M, Ciccarese C, Santini D, Alfieri S, Martignoni G, Brunelli M, Piva F, Berardi R, Montironi R, Porta C, Cascinu S, Tortora G. PD-1 blockade therapy in renal cell carcinoma: current studies and future promises. Cancer Treat Rev. 2015; 41:114-21.

31. Homet Moreno B, Ribas A. Anti-programmed cell death protein-1/ligand-1 therapy in different cancers. Br J Cancer. 2015; 112:1421-27.

32. Zou W, Chen L. Inhibitory B7-family molecules in the tumour microenvironment. Nat Rev Immunol. 2008; 8:467-77.

33. Dong H, Strome SE, Salomao DR, Tamura H, Hirano F, Flies DB, Roche PC, Lu J, Zhu G, Tamada K, Lennon VA, Celis E, Chen L. Tumor-associated B7-H1 promotes T-cell apoptosis: a potential mechanism of immune evasion. Nat Med. 2002; 8:793-800.

34. Thompson RH, Kuntz SM, Leibovich BC, Dong H, Lohse CM, Webster WS, Sengupta S, Frank I, Parker AS, Zincke H, Blute ML, Sebo TJ, Cheville JC, Kwon ED. Tumor B7$\mathrm{H} 1$ is associated with poor prognosis in renal cell carcinoma patients with long-term follow-up. Cancer Res. 2006; 66:3381-85.

35. Abiko K, Matsumura N, Hamanishi J, Horikawa N, Murakami R, Yamaguchi K, Yoshioka Y, Baba T, Konishi I, Mandai M. IFN- $\gamma$ from lymphocytes induces PD-L1 expression and promotes progression of ovarian cancer. $\mathrm{Br}$ J Cancer. 2015; 112:1501-09.

36. Nomi T, Sho M, Akahori T, Hamada K, Kubo A, Kanehiro H, Nakamura S, Enomoto K, Yagita H, Azuma M, Nakajima Y. Clinical significance and therapeutic potential of the programmed death-1 ligand/programmed death-1 pathway in human pancreatic cancer. Clin Cancer Res. 2007; 13:2151-57.

37. Wu C, Zhu Y, Jiang J, Zhao J, Zhang XG, Xu N. Immunohistochemical localization of programmed death-1 ligand-1 (PD-L1) in gastric carcinoma and its clinical significance. Acta Histochem. 2006; 108:19-24.

38. Ohigashi Y, Sho M, Yamada Y, Tsurui Y, Hamada K, Ikeda N, Mizuno T, Yoriki R, Kashizuka H, Yane K, Tsushima F, Otsuki N, Yagita $\mathrm{H}$, et al. Clinical significance of programmed death-1 ligand-1 and programmed death-1 ligand-2 expression in human esophageal cancer. Clin Cancer Res. 2005; 11:2947-53. 
39. Gao Q, Wang XY, Qiu SJ, Yamato I, Sho M, Nakajima Y, Zhou J, Li BZ, Shi YH, Xiao YS, Xu Y, Fan J. Overexpression of PD-L1 significantly associates with tumor aggressiveness and postoperative recurrence in human hepatocellular carcinoma. Clin Cancer Res. 2009; 15:971-79.

40. Dong Y, Sun Q, Zhang X. PD-1 and its ligands are important immune checkpoints in cancer. Oncotarget. 2017; 8:217186. https://doi.org/10.18632/oncotarget.13895.

41. Ota K, Azuma K, Kawahara A, Hattori S, Iwama E, Tanizaki J, Harada T, Matsumoto K, Takayama K, Takamori S, Kage M, Hoshino T, Nakanishi Y, Okamoto I. Induction of PD-L1 Expression by the EML4-ALK Oncoprotein and Downstream Signaling Pathways in Non-Small Cell Lung Cancer. Clin Cancer Res. 2015; 21:4014-21.

42. Qing Y, Li Q, Ren T, Xia W, Peng Y, Liu GL, Luo H, Yang YX, Dai XY, Zhou SF, Wang D. Upregulation of PD-L1 and APE1 is associated with tumorigenesis and poor prognosis of gastric cancer. Drug Des Devel Ther. 2015; 9:901-09.

43. Qin T, Zeng YD, Qin G, Xu F, Lu JB, Fang WF, Xue C, Zhan JH, Zhang XK, Zheng QF, Peng RJ, Yuan ZY, Zhang L, Wang SS. High PD-L1 expression was associated with poor prognosis in 870 Chinese patients with breast cancer. Oncotarget. 2015; 6:33972-81. https://doi.org/10.18632/ oncotarget.5583.

44. Shin SJ, Jeon YK, Cho YM, Lee JL, Chung DH, Park JY, Go H. The Association Between PD-L1 Expression and the Clinical Outcomes to Vascular Endothelial Growth FactorTargeted Therapy in Patients With Metastatic Clear Cell Renal Cell Carcinoma. Oncologist. 2015; 20:1253-60.

45. Okazaki T, Maeda A, Nishimura H, Kurosaki T, Honjo T. PD-1 immunoreceptor inhibits B cell receptor-mediated signaling by recruiting src homology 2-domain-containing tyrosine phosphatase 2 to phosphotyrosine. Proc Natl Acad Sci USA. 2001; 98:13866-71.

46. Chikuma S, Terawaki S, Hayashi T, Nabeshima R, Yoshida T, Shibayama S, Okazaki T, Honjo T. PD-1-mediated suppression of IL-2 production induces CD8+ T cell anergy in vivo. J Immunol. 2009; 182:6682-89.

47. Bishop KD, Harris JE, Mordes JP, Greiner DL, Rossini AA, Czech MP, Phillips NE. Depletion of the programmed death-1 receptor completely reverses established clonal anergy in CD4(+) $\mathrm{T}$ lymphocytes via an interleukin-2dependent mechanism. Cell Immunol. 2009; 256:86-91.

48. Jin HT, Ahmed R, Okazaki T. Role of PD-1 in regulating T-cell immunity. Curr Top Microbiol Immunol. 2011; 350:17-37.

49. Hikita A, Tanaka N, Yamane S, Ikeda Y, Furukawa H, Tohma S, Suzuki R, Tanaka S, Mitomi H, Fukui N. Involvement of a disintegrin and metalloproteinase 10 and 17 in shedding of tumor necrosis factor-alpha. Biochem Cell Biol. 2009; 87:581-93.

50. Zhang G, Hou J, Shi J, Yu G, Lu B, Zhang X. Soluble CD276 (B7-H3) is released from monocytes, dendritic cells and activated $\mathrm{T}$ cells and is detectable in normal human serum. Immunology. 2008; 123:538-46.
51. Jeannin P, Magistrelli G, Aubry JP, Caron G, Gauchat JF, Renno T, Herbault N, Goetsch L, Blaecke A, Dietrich PY, Bonnefoy JY, Delneste Y. Soluble CD86 is a costimulatory molecule for human $\mathrm{T}$ lymphocytes. Immunity. 2000; 13:303-12.

52. Oaks MK, Hallett KM. Cutting edge: a soluble form of CTLA-4 in patients with autoimmune thyroid disease. J Immunol. 2000; 164:5015-18.

53. Sorensen SF, Demuth C, Weber B, Sorensen BS, Meldgaard $\mathrm{P}$. Increase in soluble PD-1 is associated with prolonged survival in patients with advanced EGFR-mutated nonsmall cell lung cancer treated with erlotinib. Lung Cancer. 2016; 100:77-84.

54. Wang L, Wang H, Chen H, Wang WD, Chen XQ, Geng QR, Xia ZJ, Lu Y. Serum levels of soluble programmed death ligand 1 predict treatment response and progression free survival in multiple myeloma. Oncotarget. 2015; 6:4122836. https://doi.org/10.18632/oncotarget.5682.

55. Nielsen C, Ohm-Laursen L, Barington $\mathrm{T}$, Husby $\mathrm{S}$, Lillevang ST. Alternative splice variants of the human PD-1 gene. Cell Immunol. 2005; 235:109-16.

56. Wan B, Nie H, Liu A, Feng G, He D, Xu R, Zhang Q, Dong $\mathrm{C}$, Zhang JZ. Aberrant regulation of synovial $\mathrm{T}$ cell activation by soluble costimulatory molecules in rheumatoid arthritis. J Immunol. 2006; 177:8844-50.

57. Chen Y, Wang Q, Shi B, Xu P, Hu Z, Bai L, Zhang X. Development of a sandwich ELISA for evaluating soluble PD-L1 (CD274) in human sera of different ages as well as supernatants of PD-L1+ cell lines. Cytokine. 2011; 56:231-38.

58. He XH, Xu LH, Liu Y. Identification of a novel splice variant of human PD-L1 mRNA encoding an isoformlacking Igv-like domain. Acta Pharmacol Sin. 2005; 26:462-68.

59. Frigola $\mathrm{X}$, Inman BA, Krco CJ, Liu X, Harrington SM, Bulur PA, Dietz AB, Dong H, Kwon ED. Soluble B7-H1: differences in production between dendritic cells and $\mathrm{T}$ cells. Immunol Lett. 2012; 142:78-82.

60. Frigola X, Inman BA, Lohse CM, Krco CJ, Cheville JC, Thompson RH, Leibovich B, Blute ML, Dong H, Kwon ED. Identification of a soluble form of B7-H1 that retains immunosuppressive activity and is associated with aggressive renal cell carcinoma. Clin Cancer Res. 2011; 17:1915-23.

61. Takahashi N, Iwasa S, Sasaki Y, Shoji H, Honma Y, Takashima A, Okita NT, Kato K, Hamaguchi T, Yamada Y. Serum levels of soluble programmed cell death ligand 1 as a prognostic factor on the first-line treatment of metastatic or recurrent gastric cancer. J Cancer Res Clin Oncol. 2016; 142:1727-38.

62. Rossille D, Gressier M, Damotte D, Maucort-Boulch D, Pangault C, Semana G, Le Gouill S, Haioun C, Tarte K, Lamy T, Milpied N, Fest T, Damaj G, et al, and Groupe Ouest-Est des Leucémies et Autres Maladies du Sang, and Groupe Ouest-Est des Leucémies et Autres Maladies du 
Sang. High level of soluble programmed cell death ligand 1 in blood impacts overall survival in aggressive diffuse large B-Cell lymphoma: results from a French multicenter clinical trial. Leukemia. 2014; 28:2367-75.

63. Ruf M, Moch H, Schraml P. PD-L1 expression is regulated by hypoxia inducible factor in clear cell renal cell carcinoma. Int J Cancer. 2016; 139:396-403.

64. Wang X, Ni S, Chen Q, Ma L, Jiao Z, Wang C, Jia G. Bladder cancer cells induce immunosuppression of $\mathrm{T}$ cells by supporting PD-L1 expression in tumour macrophages partially through interleukin 10. Cell Biol Int. 2017; 41:177-86.

65. Lipson EJ, Forde PM, Hammers HJ, Emens LA, Taube JM, Topalian SL. Antagonists of PD-1 and PD-L1 in Cancer Treatment. Semin Oncol. 2015; 42:587-600.

66. He L, Zhang G, He Y, Zhu H, Zhang H, Feng Z. Blockade of B7-H1 with sPD-1 improves immunity against murine hepatocarcinoma. Anticancer Res. 2005; 25:3309-13.

67. Elhag OA, Hu XJ, Wen-Ying Z, Li X, Yuan YZ, Deng LF, Liu DL, Liu YL, Hui G. Reconstructed adeno-associated virus with the extracellular domain of murine PD-1 induces antitumor immunity. Asian Pac J Cancer Prev. 2012; 13:4031-36.

68. Dolan DE, Gupta S. PD-1 pathway inhibitors: changing the landscape of cancer immunotherapy. Cancer Contr. 2014; 21:231-37.

69. Brahmer JR, Hammers H, Lipson EJ. Nivolumab: targeting PD-1 to bolster antitumor immunity. Future Oncol. 2015; 11:1307-26.

70. Martin-Liberal J, Kordbacheh T, Larkin J. Safety of pembrolizumab for the treatment of melanoma. Expert Opin Drug Saf. 2015; 14:957-64.

71. Bryan LJ, Gordon LI. Pidilizumab in the treatment of diffuse large B-cell lymphoma. Expert Opin Biol Ther. 2014; 14:1361-68.

72. Antonia S, Goldberg SB, Balmanoukian A, Chaft JE, Sanborn RE, Gupta A, Narwal R, Steele K, Gu Y, Karakunnel JJ, Rizvi NA. Safety and antitumour activity of durvalumab plus tremelimumab in non-small cell lung cancer: a multicentre, phase 1b study. Lancet Oncol. 2016; 17:299-308.

73. Vansteenkiste J, Wauters E, Park K, Rittmeyer A, Sandler A, Spira A. Prospects and progress of atezolizumab in non-small cell lung cancer. Expert Opin Biol Ther. 2017; 17:781-89.

74. Song MY, Park SH, Nam HJ, Choi DH, Sung YC. Enhancement of vaccine-induced primary and memory CD8(+) T-cell responses by soluble PD-1. J Immunother. 2011; 34:297-306.

75. Geng H, Zhang GM, Xiao H, Yuan Y, Li D, Zhang H, Qiu $\mathrm{H}$, He YF, Feng ZH. HSP70 vaccine in combination with gene therapy with plasmid DNA encoding sPD-1 overcomes immune resistance and suppresses the progression of pulmonary metastatic melanoma. Int J Cancer. 2006; 118:2657-64.
76. Cheng HY, Kang PJ, Chuang YH, Wang YH, Jan MC, Wu CF, Lin CL, Liu CJ, Liaw YF, Lin SM, Chen PJ, Lee SD, Yu MW. Circulating programmed death-1 as a marker for sustained high hepatitis B viral load and risk of hepatocellular carcinoma. PLoS One. 2014; 9:e95870.

77. Zhang P, Ouyang S, Wang J, Huang Z, Wang J, Liao L. [Levels of programmed death-1 and programmed death ligand-1 in the peripheral blood of patients with oral squamous cell carcinoma and its clinical implications]. Hua Xi Kou Qiang Yi Xue Za Zhi. 2015; 33:529-33.

78. Cheng S, Zheng J, Zhu J, Xie C, Zhang X, Han X, Song B, Ma Y, Liu J. PD-L1 gene polymorphism and high level of plasma soluble PD-L1 protein may be associated with non-small cell lung cancer. Int J Biol Markers. 2015; 30:e364-68.

79. Finkelmeier F, Canli Ö, Tal A, Pleli T, Trojan J, Schmidt M, Kronenberger B, Zeuzem S, Piiper A, Greten FR, Waidmann O. High levels of the soluble programmed deathligand (sPD-L1) identify hepatocellular carcinoma patients with a poor prognosis. Eur J Cancer. 2016; 59:152-59.

80. Huang SY, Lin HH, Lin CW, Li CC, Yao M, Tang JL, Hou HA, Tsay W, Chou SJ, Cheng CL, Tien HF. Soluble PD-L1: A biomarker to predict progression of autologous transplantation in patients with multiple myeloma. Oncotarget. 2016; 7:62490-502. https://doi.org/10.18632/ oncotarget.11519.

81. Zheng Z, Bu Z, Liu X, Zhang L, Li Z, Wu A, Wu X, Cheng X, Xing X, Du H, Wang X, Hu Y, Ji J. Level of circulating PD-L1 expression in patients with advanced gastric cancer and its clinical implications. Chin J Cancer Res. 2014; 26:104-11.

82. Okuma Y, Hosomi Y, Nakahara Y, Watanabe K, Sagawa Y, Homma S. High plasma levels of soluble programmed cell death ligand 1 are prognostic for reduced survival in advanced lung cancer. Lung Cancer. 2017; 104:1-6.

83. Siegel R, Naishadham D, Jemal A. Cancer statistics, 2012. CA Cancer J Clin. 2012; 62:10-29.

84. Chen W, Zheng R, Baade PD, Zhang S, Zeng H, Bray F, Jemal A, Yu XQ, He J. Cancer statistics in China, 2015. CA Cancer J Clin. 2016; 66:115-32.

85. Wong RJ, Ahmed A, Gish RG. Elevated alpha-fetoprotein: differential diagnosis - hepatocellular carcinoma and other disorders. Clin Liver Dis. 2015; 19:309-23.

86. Grunnet M, Sorensen JB. Carcinoembryonic antigen (CEA) as tumor marker in lung cancer. Lung Cancer. 2012; $76: 138-43$.

87. Li Y, Li DJ, Chen J, Liu W, Li JW, Jiang P, Zhao X, Guo F, Li XW, Wang SG. Application of Joint Detection of AFP, CA19-9, CA125 and CEA in Identification and Diagnosis of Cholangiocarcinoma. Asian Pac J Cancer Prev. 2015; 16:3451-55.

88. Vertosick EA, Poon BY, Vickers AJ. Relative value of race, family history and prostate specific antigen as indications 
for early initiation of prostate cancer screening. J Urol. 2014; 192:724-28.

89. Fiume L, Manerba M, Vettraino M, Di Stefano G. Inhibition of lactate dehydrogenase activity as an approach to cancer therapy. Future Med Chem. 2014; 6:429-45.

90. Tan S, Chen D, Liu K, He M, Song H, Shi Y, Liu J, Zhang CW, Qi J, Yan J, Gao S, Gao GF. Crystal clear: visualizing the intervention mechanism of the PD-1/PD-L1 interaction by two cancer therapeutic monoclonal antibodies. Protein Cell. 2016; 7:866-77.
91. Pan XC, Li L, Mao JJ, Yao W, Zheng JN, Liu M, Fu JJ. Synergistic effects of soluble PD-1 and IL-21 on antitumor immunity against H22 murine hepatocellular carcinoma. Oncol Lett. 2013; 5:90-96.

92. Zatloukalová P, Pjechová M, Babčanová S, Hupp TR, Vojtěšek B. [The Role of PD-1/PD-L1 Signaling Pathway in Antitumor Immune Response]. Klin Onkol. 2016 (Suppl 4); 29:72-77. 